\begin{tabular}{|l|l|c|l|}
\hline 每曲 & Received: 30 May 2018 & 压 & Published: 31 October 2018 \\
\hline
\end{tabular}

\title{
PERCEIVED STRESS LEVEL AMONG MADRASAH 'ALIYAH STUDENTS DURING EXAMINATION WEEK
}

\author{
Muhammad Fijar Rotul Akbar, Achmad Rizki, Maulida Nur \\ E-mail: ${ }^{1}$ vzhar.akbar@gmail.com, ${ }^{2}$ rizkialisumar169@gmail.com, ${ }^{3}$ maulidanur@upi.edu \\ ${ }^{1}$ University of Malaya, Kuala Lumpur, Malaysia \\ ${ }^{2}$ Ibnu Khaldun University, Bogor, Indonesia \\ ${ }^{3}$ Indonesia University of Education, Bandung, Indonesia
}

\begin{tabular}{l} 
ABSTRACT \\
Academic demands including examinations are found to be \\
the major contributor of stress development among students. \\
Current research is purposed to investigate the prevalence of \\
perceived stress level among Madrasah Aliyah students \\
during examination week. This study was a descriptive and \\
cross-sectional design applying quantitative method for data \\
collection. With respect to the sample, 107 students form \\
Madrasah Aliyah \\
proportionally selected from class 10 to class 12 . To measure \\
the degree to which particular situations and conditions \\
happening in student's life are appraised or perceived as \\
stressful situation, Perceived Stress Scale developed by \\
Sheldon Cohen was administered. After which, having \\
gained ethical approval from the foundation board and \\
school director, the data were collected and analyzed using \\
statistical program of SPSS. Result showed that during \\
examination, majority of them were experiencing moderate \\
level of stress accounting for more than 80\% and no \\
significant differences of stress level were found with \\
respect to gender, age and study year (class). \\
\hline \hline
\end{tabular}

\section{INTRODUCTION}

Exam-related stress is most likely to occur when students are not able to generate any coping strategies to deal with stressful situations which start from revisions and runs-up week to the actual periods of examination (Bosch, Ring, \& Amerongen, 2004; Pollard, Steptoe, Canaan, Davies, \& Wardle, 1995). During which times, students may feel pressure from school and family expectation to academically excel or become perturbed about failure as well as obtaining result less than what they expected (Abouserie, 1994; Macgeorge, Samter, \& Gillihan, 2005; Misra \& McKean, 2000; Pollard et al., 1995). In 
regular condition, feeling stress and nervous is actually helpful to enhance performance but overwhelming stress and excessive anxiety definitely lead toward inability to perform well during examination (Barker, Barker, McCain, \& Schubert, 2016; A.P. Kahn \& Meyer, 2006; Krohne, 2002). Relating to that, a vast amount of literature and studies linked to stress among students have been well documented and have cited that school as major contributor to the development of students' stress (Barker et al., 2016; Park \& Kim, 2018). Scientific studies revealed that majority of students in all parts of the world including Indonesia are mainly dealing with academic issues, and the imprudent academic pressure to perform better specifically during examination are quite high in this country (Taufik, Ifdil, \& Ardi, 2013; Wardana \& Dinata, 2016).

According to survey conducted by a leading psychologist in Indonesia, it was revealed that $44 \%$ of Indonesian students feel stressed when they have quiz, assignments and moreover examination (Maharani, 2015). Similarly, a study conducted by Kinantie (2012) pertaining students' stress in a public secondary school in Bandung, Indonesia showed that $30 \%$ of students were experiencing high stress level prior to national examination. Further, $35.35 \%$ students of a high school in Bali are reported to face medium level of stress before exam as well (Wardana \& Dinata, 2016). Therefore, given the fact that exam stress is a major stressful experience for students, the elevated exam stress has been also evident to be associated with underachievement (Elias, Ping, \& Abdullah, 2011; $\mathrm{Ng}$, Koh, \& Chia, 2003), less motivation to achieve better grade (Austin, Saklofske, \& Mastoras, 2010), increased level of tension and depression (Ang \& Huan, 2006; Dahlin, Joneborg, \& Runeson, 2005; Dixon \& Kurpius, 2008; Kumaraswamy, 2013; Shaikh et al., 2004), self-control impairment (Oaten \& Cheng, 2005), also negative influence on physiological indicators of stress and immune function (Gilbert, Stunkard, Jensen, Detwiler, \& Martinko, 1996). All together, these findings suggest that certain negative occurrences like poor performance during exam and other outcomes are also correlated with exam stress aside from other factors, this highlight the necessity for further analysis and research as well as the need for effective intervention for them.

With respect to Madrasah Aliyah, in the jurisdictions of Indonesia, the term of Madrasah Aliyah refers to statutory formal education of secondary school which starting from grade ten to grade twelve in which its system and administration is under Ministry of Religious Affairs (Departemen Agama, 1985; Indonesia, 1994). Like any other senior high schools, Madrasah Aliyah offers a wide array of study programs such as natural or social science, vocational and even language programs. During final years, students of Madrasah Aliyah are also required to be seated for National Examinations. Regarding their curriculum and states, Madrasah Aliyah is the same as any public or private school, but the portions for Islamic Education are relatively higher due to the additions of certain subjects like $A l$ Qur'an and Hadith, Tafsir, Fiqh, Aqidah, Arabic Language, Islamic History and many more (Departemen Agama, 1985; Indonesia, 1994). Correspondingly, students of all secondary schools encompassing Madrasah Aliyah have similar potential to experience academic stress moreover during examination weeks, and specifically when their resources to cope with certain perceived troublesome situations are not fully generated (Hakiqi, 2013; Sholiha, 2013; Sulaeman \& Joefiani, 2014). In such, many researchers have documented a wide array of studies pertaining examination-related stress to be prevalent among 
secondary school students, but little attention has been given to its especially madrasah aliyah students whereas those students have to deal with additional numbers of subjects examined compared to regular secondary school (Fuad, 2015; Hakiqi, 2013; Sholiha, 2013).

Consequently, this starts to be deteriorating for some schools have limited access toward mental health care due to the deprivation of proper interventions, unavailability of counseling staff or any human factors dealing with students' wellness (Putri, 2013), and susceptible scarceness toward discussion about this problems owing to cultural and traditional factors (Baruth \& Manning, 2016; Jaladin, 2018; Pope-Davis, 2003). Finally, with the intention and goals to motivate Madrasah Aliyah students to academically perform better and to encourage them to be resilient students, this research is conducted with the focus on assessing the prevalence of perceived level of stress during examination week. Next, coming from mentioned reasons, the study was conducted to answer following research questions 1) What is the perceived level of stress among Madrasah Aliyah students? And 2) Does the pervasiveness of perceived stress level among Madrasah Aliyah students statistically differ if associated to their gender and study year (level)? Further, the research possessed only one hypothesis stating that there were significant differences of stress level when linked to gender, age and year of study. The reason was that stress level may vary from low to high level depend on several factors like age, gender, study of years and many more.

This study was descriptive and cross sectional design in which it applied qualitative method to collect the data and random sampling to determine total of respondents. Prior to conduct the study, researchers asked for ethical approval from the school director and management to conduct the research in this very school. Having gained the approval from school director and management board, 107 respondents were recruited; those respondents are students of Madrasah Aliyah Pasirjambu, Kab. Bandung from year 10 to year 12 who were proportionally recruited to participate in this research whereby they were asked to fill up paper-based questionnaire regarding their perception of stress in a designated class room immediately after exam during examination week of second semester. The questionnaire took around 15 to 30 minutes to be completed by the respondents. The process of data collection required four days for completions in which respondents were gradually recruited from year 10 to year 12, and within the fourth day, the data were checked for completion and those found to be incomplete were replaced in the same day.

The questionnaire to assess perceived stress level among Madrasah Aliyah students was divided into two sections; the first part covers demographic information about the respondents whereby they were asked to report their age, gender, year of study, and how many exams they had sat during recent exam period. As for measurement, Perceived Stress Scale developed by Sheldon Cohen, Kammarck and Mermelstein $(1983 ; 1994)$ to measure the degree to which situations in student's life are perceived as stressful situation, or in this case is the degree to which students perceived examinations as stressful events. The measure has been used in various studies such as Academic Stress Impairs SelfControl by Oaten and Cheng (2005) or Stress, Social Support and Health-related Behaviour by Steptoe, Wardle, Pollard, Canaan, and Davies (1996). The reliability of the questionnaire was using Cronbach Alpha and the result was quite reliable at .084.

Perceived Stress Level Among Madrasah 'Aliyah Students During Examination Week | 119 
This questionnaire is $0-4$ likert-scale that has 10 questions in which each number asks respondents about their feelings, thought, and assumption within last months. Next, respondents were asked to rate and indicate how frequent they perceived in a certain way like 0 - for Never, 1 - for Almost Never, 2 - for Sometimes, 3 - for Fairly Often, 4 - for Very Often. Furthermore, to assess level of stress, score for number 4, 5, 7 and 8 have to be reversed, and the change of score would be $0=4,1=3,2=2,3=1$, and $4=0$. Following that, all score should be added up for each item to obtain score total. In the end of calculation, score obtained on this questionnaire can range from 0 to 40 in which higher score indicates higher perceived stress. Score from 0 to 13 would be determined as low stress, 14 to 26 would be considered moderate stress and score ranging from 27 to 40 would be considered high level of perceived stress (Cohen et al., 1983; Cohen et al., 1994).

Turning to the analysis, researchers used SPSSv20 to analyse collected data. The prevalence and percentage of perceived stress level among Madrasah Aliyah students was scrutinized using descriptive statistics while statistical differences associated with gender, ages and study year were analysed non-parametric test in which gender variable was investigated using Mann-Whitney $U$ test, and both ages and study year (level) were analysed using Krusskal-Wallis Test.

\section{RESULTS AND DISCUSSION}

\section{Baseline Characteristics of Respondents}

The respondents were students aged 15 to 18 years $(M=1.50, S D=.502) .49 .5 \%$ were male $(n=53)$ and $50.5 \%$ were female $(n=54)$. Regarding year of study, twenty-five point three per cents of respondents were reported to be studying at level $10(n=26)$, thirty-eight point three were in level 11 at forty-one students and students of level 12 was thirty-seven point four at fort students. The information can be seen at table 1 .

Table 1

Respondents' Baseline Characteristics

\begin{tabular}{cccc}
\hline \multicolumn{2}{c}{ Variables } & $\mathbf{N}$ & $\mathbf{\%}$ \\
\hline \multirow{3}{*}{ Gender } & & & \\
& Male & 53 & 49.5 \\
\multirow{4}{*}{ Age } & Female & 54 & 50.5 \\
& & & \\
& 15 & 22 & 20.6 \\
& 16 & 38 & 35.5 \\
Level/ Class & 17 & 37 & 34.6 \\
& 18 & 10 & 9.3 \\
& 10 & 26 & 24.3 \\
& 11 & 41 & 38.3 \\
& 12 & 40 & 37.4 \\
\hline
\end{tabular}




\section{Perceived Level of Stress}

Table 2

Distribution of Perceived Level of Stress According to Gender, Age, and Class (Year of Study)

\begin{tabular}{|c|c|c|c|c|}
\hline Varial & & Low & Moderate & High \\
\hline \multicolumn{5}{|l|}{ Gender } \\
\hline & Male & 1 & 50 & 2 \\
\hline & Female & 4 & 47 & 3 \\
\hline & & & 107 & \\
\hline \multicolumn{5}{|l|}{ Age } \\
\hline & 15 & 0 & 21 & 1 \\
\hline & 16 & 2 & 33 & 3 \\
\hline & 17 & 2 & 34 & 1 \\
\hline & 18 & 1 & 9 & 0 \\
\hline & & & 107 & \\
\hline \multicolumn{5}{|l|}{ Level/ Class } \\
\hline & 10 & 1 & 23 & 2 \\
\hline & 11 & 2 & 38 & 2 \\
\hline & 12 & 3 & 36 & 1 \\
\hline & & & 107 & \\
\hline
\end{tabular}

Table 2 illustrates the distribution of perceived level of stress associated with gender, age and year of study. Accordingly, this result was to answer the research question number one. Overall, it was evident that majority of students were experiencing moderate level of stress during examination week, and both low and high stress level were given the lowest number with similar point.

If seen from gender variable, moderate stress level was the most predominant number accounting for almost total of respondents at 97 while remaining stress levels gained the lowest number at 5 for each. Similar distribution was given to age and study year variable in which most students experienced medium level of stress in the period of examination at 97 and 5 for each low and high level of stress. 
IJISH, Volume 1, Number 2, October 2018: 117-127

\section{Statistical Differences of Variable in Questions}

Table 3

Differences of Perceived Level of Stress According to Gender, Age, and Class

\begin{tabular}{cc}
\hline Variables & Statistical Differences \\
\hline \hline Gender & $\mathrm{U}=1417, p=.930$ \\
Age & $\mathrm{X}^{2}=1.025, p=.795$ \\
Level/ Class & $\mathrm{X}^{2}=962, p=.618$ \\
\hline
\end{tabular}

For the measure to test whether there were any differences in level of perceived stress if linked to students' gender, age and year of study (class) some statistical calculation were done but surprisingly the result showed that there were no significant different in level of perceived stress according to gender, age and year of study. Therefore, nul hypothesis was failed to be rejected as there were no statistical differences among those variables. Information regarding this result can be found in table 3 .

The research was conducted to examine the prevalence of perceived stress level of students in Madrasah Aliyah during examination week with the baseline of gender, age, and year of study were being reported. Unsurprisingly, the result showed that stress related examination was experienced by students of Madrasah Aliyah starting from low level to high level within those periods for several factors such mentioned external and internal demands which made them anxious and feeling pressured. In accordance to that matter, the result of pervasiveness of stress was consistent with a wide range of previous studies in the same area (Arnett, 1999; Bosch et al., 2004; Gilbert et al., 1996; Lal, 2014; Macgeorge et al., 2005; Ng et al., 2003; Pollard et al., 1995; Shaikh et al., 2004; Sulaeman \& Joefiani, 2014; Weinstein \& Laverghetta, 2009) whereby those findings demonstrated that academic stress including examination stress were major trigger for stress development. It is actually a common occurrence that during exam students may perceive their current situation as overwhelming, stressful and hopeless, often, those situations were fueled by a wide array of reasons such demands like has been discussed concurrently and others like low mood. Scientifically, students' perception regarding their stress may be nothing other than a few pathways in brain being temporarily compromised to tackle stressful situation (Gilbert et al., 1996; Ada P Kahn, 2006; Krohne, 2002; Lazarus \& DeLongis, 1983).

Nevertheless, when such conditions were being ignored specifically during adolescence without proper interventions and rational justification coming from external resources, it may become a pathway toward psychopathology (Compas \& Andreotti, 2013; Grant, Compas, Thurm, McMahon, \& Gipson, 2004). Furthermore, the finding of current study on stress level supported past studies regarding secondary school stress conducted by Kinantie (2012) who found that $49 \%$ of students in a public school in Bandung were having mild stress and $30 \%$ of them were heavily stressed prior to national examination. Another finding with almost similar result was the study conducted by Wardana and Dinata (2016). 
Regarding the association between level of stress and other variables - gender age - and year of study, the result contradicted the finding suggesting that stress among medical college students in final years of education was linked to gender (V Backović, Ilic Zivojinovic, Maksimović, \& Maksimović, 2012). Similarly, current research was inconsistent with the research conducted by Pourrajab, Rabbani, and Kasmaienezhadfard (2014) and Mazumdar, Gogoi, Buragohain, and Haloi (2012) also Chaplin, Hong, Bergquist, and Sinha (2008) who suggested that stress rate among female students was higher than male was due to having regularly various stress symptoms, different attitude toward environment and tendency to become emotional. The contradictions among these findings may be several reasons such as difference age, level of education, location, culture and others but mostly due to different population whereby current research was emphasized on secondary school population while mentioned research was conducted among college students. Nevertheless, a study done by Berry and Kingswell (2012) about adult attachment and coping with exam stress also Kania (2014) among Western University students during math test documented finding which closely agreed with current research. As for association among level of stress and age also study year variable, no significant difference were found here. This conflicted past study about stress, coping and appraisal (Aldwin, Sutton, Chiara, \& Spiro, 1996) which reported that level of stress varied with regard to age differences or study concerning age differences in stress, coping and which ways of coping mediate relationship between age and positive affect (Chen, Peng, Xu, \& O'Brien, 2018).

All in all, inconsistency among this findings were seem to be related to different populations and locations as people - children - teenagers - adult - and middle age definitely deal with distinctive circumstances (Corey, 2013; Sharf, 2012). This study possessed several limitations including the narrow population which covers only one particular school whereas larger number of respondents would allow for more accurate and exact representation of population in interest and definitely would allow variety of assessments and analysis. Another limitation was the research construction was quite simple whereby the research was conducted in descriptive design whereas the discussion could be much deeper when applying the correlational design for such broad area of study. In addition to that, more rigorous research relating stressor, stress, academic stress, perceived stress level and even coping should be conducted to gain holistic understanding about stress. It is highly recommended for future studies to gain more regarding stressor and coping strategies in which students can generate during stressful situation like examinations, presentation or regular assignments.

\section{CONCLUSION}

As for conlusion, this research clarified that exam-related stress was prevalent and relevant among students, the need toward future research regarding ways of coping during examination week and analysis about it is extremely recommended as knowledge about effective coping strategies during examination will help them release tense and stress, feel relaxed and positive when they sit for exam (Aldwin et al., 1996; Austin et al., 2010; Berry \& Kingswell, 2012; Krohne, 2002; Lazarus \& DeLongis, 1983; Martyn-Nemeth, Penckofer, Gulanick, Velsor-Friedrich, \& Bryant, 2009; Park \& Kim, 2018). As consequences, not only do the students have great opportunity to academically excel, they 
grow to be mentally health persons. Further, it is hoped that counseling staff in Madrasah Aliyah could provide fine interventions to help them handle their stress problem specifically during examination. Finally, researchers would like to quote a verse from Al Quran in concurrence with the very topic about exam related-stress to motivate and encourage students when they experience stressful situation during which periods.

"Be sure We will test you with something of fear and hunger, some loss in goods or lives, but give glad tidings to those who are steadfast, who say when afflicted with calamity: To God we belong and to Him is our return. They are those on whom (descend) blessings from God and mercy and they are the ones that receive guidance." (Quran 2:155)

\section{REFERENCES}

Abouserie, R. (1994). Perceived academic stress, gender and subject of study in university students. Welsh Journal of Education, 4(1), 40-44.

Aldwin, C. M., Sutton, K. J., Chiara, G., \& Spiro, I. I. I. A. (1996). Age Differences in Stress, Coping, and Appraisal: Findings from the Normative Aging Study. The Journals of Gerontology: Series B, 51B(4), P179-P188. doi:10.1093/geronb/51B.4.P179

Ang, R. P., \& Huan, V. S. (2006). Relationship between academic stress and suicidal ideation: Testing for depression as a mediator using multiple regression. Child psychiatry and human development, 37(2), 133.

Arnett, J. J. (1999). Adolescent storm and stress, reconsidered. American psychologist, 54(5), 317.

Austin, E. J., Saklofske, D. H., \& Mastoras, S. M. (2010). Emotional intelligence, coping and exam-related stress in Canadian undergraduate students. Australian Journal of Psychology, 62(1), 42-50.

Barker, S. B., Barker, R. T., McCain, N. L., \& Schubert, C. M. (2016). A Randomized Cross-over Exploratory Study of the Effect of Visiting Therapy Dogs on College Student Stress Before Final Exams. Anthrozoös, 29(1), 35-46. doi:10.1080/08927936.2015.1069988

Baruth, L. G., \& Manning, M. L. (2016). Multicultural counseling and psychotherapy: A lifespan approach: Routledge.

Berry, K., \& Kingswell, S. (2012). An investigation of adult attachment and coping with exam-related stress. British Journal of Guidance \& Counselling, 40(4), 315-325. doi:10.1080/03069885.2012.685861

Bosch, J. A., Ring, C., \& Amerongen, A. V. N. (2004). Academic examinations and immunity: academic stress or examination stress? Psychosomatic medicine, 66(4), 625-626.

Chaplin, T. M., Hong, K., Bergquist, K., \& Sinha, R. (2008). Gender Differences in Response to Emotional Stress: An Assessment Across Subjective, Behavioral, and Physiological Domains and Relations to Alcohol Craving. Alcoholism, clinical and experimental research, 32(7), 1242-1250. doi:10.1111/j.1530-0277.2008.00679.x 
Chen, Y., Peng, Y., Xu, H., \& O'Brien, W. H. (2018). Age Differences in Stress and Coping: Problem-Focused Strategies Mediate the Relationship Between Age and Positive Affect. Int J Aging Hum Dev, 86(4), 347-363. doi: $10.1177 / 0091415017720890$

Cohen, S., Kamarck, T., \& Mermelstein, R. (1983). A global measure of perceived stress. Journal of health and social behavior, 385-396.

Cohen, S., Kamarck, T., \& Mermelstein, R. (1994). Perceived stress scale. Measuring stress: A guide for health and social scientists.

Compas, B., \& Andreotti, C. (2013). Risk and resilience in child and adolescent psychopathology. Child and adolescent psychopathology, 143-170.

Corey, G. (2013). Theory and Practice of Counseling and Psychotherapy (9th ed.). Belmont, CA, USA: Brooks/Cole Cengage Learning.

Dahlin, M., Joneborg, N., \& Runeson, B. (2005). Stress and depression among medical students: a cross-sectional study. Med Educ, 39(6), 594-604. doi:10.1111/j.13652929.2005.02176.x

Departemen Agama, R. (1985). Pedoman Umum Kurikulum Madrasah Ibtidaiyah, Madrasah Tsanawiyah, Madrasah Aliyah dan Garis-garis Besar Program Pengajaran. Jakarta, Direktorat Jendral Pembinaan.

Dixon, S. K., \& Kurpius, S. E. R. (2008). Depression and college stress among university undergraduates: Do mattering and self-esteem make a difference? Journal of College Student Development, 49(5), 412-424.

Elias, H., Ping, W. S., \& Abdullah, M. C. (2011). Stress and academic achievement among undergraduate students in Universiti Putra Malaysia. Procedia-Social and Behavioral Sciences, 29, 646-655.

Fuad, Z. (2015). Tingkat Stress dan Stressor Pada Pelajar Pesantren di Banda Aceh. (Bachelor), University of Syah Kuala, Banda Aceh.

Gilbert, D. G., Stunkard, M. E., Jensen, R. A., Detwiler, F. R., \& Martinko, J. M. (1996). Effects of exam stress on mood, cortisol, and immune functioning: Influences of neuroticism and smoker-non-smoker status. Personality and Individual Differences, 21(2), 235-246.

Grant, K. E., Compas, B. E., Thurm, A. E., McMahon, S. D., \& Gipson, P. Y. (2004). Stressors and child and adolescent psychopathology: Measurement issues and prospective effects. Journal of Clinical Child and Adolescent Psychology, 33(2), $412-425$.

Hakiqi, S. A. (2013). Perbedaan Tingkat Depresi Remaja Madrasah Aliyah al-Qodiri yang Tinggal di Rumah dan di Pondok Pesantren al-Qodiri Kecamatan. (Bachelor), Universitas Jember, jember, Indonesia.

Indonesia, D. A. R. (1994). Kurikulum Madrasah Aliyah, Petunjuk Pelaksanaan proses Belajar Mengajar: Jakarta: Dirjen Pembinaan Kelembagaan Agama Islam.

Jaladin, R. A. M. (2018). Multicultural Counselling. Book Draft. Faculty of Education, University of Malaya. Kuala Lumpur.

Kahn, A. P. (2006). The encyclopedia of stress and stress-related diseases: Infobase Publishing. 
Kahn, A. P., \& Meyer, D. H. (2006). The Encyclopedia of Stress and Stress-Related Diseases, Second Edition: Facts on File.

Kania, S. K. (2014). The relationship between gender differences and stress. The Huron University College Journal of Learning and Motivation, 52(1), 7.

Kinantie, O. A. (2012). Gambaran Tingkat Stres Siswa SMAN 3 Bandung Kelas XII Menjelang Ujian Nasional 2012. Students e-Journal, 1(1), 31.

Krohne, H. W. (2002). Stress and coping theories. International Encyclopedia of the Social Behavioral Sceinces, 22, 15163-15170.

Kumaraswamy, N. (2013). Academic stress, anxiety and depression among college students-a brief review. International review of social sciences and humanities, 5(1), 135-143.

Lal, K. (2014). Academic stress among adolescent in relation to intelligence and demographic factors. American International Journal of Research in Humanities, Arts and Social Sciences, 5(1), 123.

Lazarus, R. S., \& DeLongis, A. (1983). Psychological stress and coping in aging. American psychologist, 38(3), 245.

Macgeorge, E. L., Samter, W., \& Gillihan, S. J. (2005). Academic Stress, Supportive Communication, and Health A version of this paper was presented at the 2005 International Communication Association convention in New York City. Communication Education, 54(4), 365-372.

Maharani, E. (2015). Psikolog: 44 Persen Remaja Stres Hadapi Ujian. Republika. Retrieved from https://republika.co.id/berita/pendidikan/eduaction/15/03/04/nkoeffpsikolog-44-persen-remaja-stres-hadapi-ujian

Martyn-Nemeth, P., Penckofer, S., Gulanick, M., Velsor-Friedrich, B., \& Bryant, F. B. (2009). The relationships among self-esteem, stress, coping, eating behavior, and depressive mood in adolescents. Research in nursing \& health, 32(1), 96-109.

Mazumdar, H., Gogoi, D., Buragohain, L., \& Haloi, N. (2012). A comparative study on stress and its contributing factors among the graduate and post-graduate students. Advances in Applied Science Research, 3(1), 399-406.

Misra, R., \& McKean, M. (2000). College students' academic stress and its relation to their anxiety, time management, and leisure satisfaction. American Journal of Health Studies, 16(1), 41.

Ng, V., Koh, D., \& Chia, S.-E. (2003). Examination stress, salivary cortisol, and academic performance. Psychological reports, 93(3_suppl), 1133-1134.

Oaten, M., \& Cheng, K. (2005). Academic examination stress impairs self-control. Journal of social and clinical psychology, 24(2), 254-279.

Park, S.-H., \& Kim, Y. (2018). Ways of coping with excessive academic stress among Korean adolescents during leisure time. International Journal of Qualitative Studies on Health and Well-being, 13(1), 1505397. doi:10.1080/17482631.2018.1505397

Pollard, T. M., Steptoe, A., Canaan, L., Davies, G. J., \& Wardle, J. (1995). Effects of academic examination stress on eating behavior and blood lipid levels. International Journal of Behavioral Medicine, 2(4), 299. 
Pope-Davis, D. B. (2003). Handbook of Multicultural Competencies in Counseling and Psychology: SAGE Publications.

Pourrajab, M., Rabbani, M., \& Kasmaienezhadfard, S. (2014). Different Effects of Stress on Male and Female Students (Vol. 3).

Putri, S. (2013). Profil Perilaku Bullying di Pesantren dan Implikasinya terhadap Bimbingan dan Konseling Pribadi Sosial. (Bachelor), Universitas Pendidikan Indonesia, Bandung, Indonesia.

Shaikh, B. T., Kahloon, A., Kazmi, M., Khalid, H., Nawaz, K., Khan, N., \& Khan, S. (2004). Students, stress and coping strategies: a case of Pakistani medical school. EDUCATION FOR HEALTH-ABINGDON-CARFAX PUBLISHING LIMITED-, 17, 346-353.

Sharf, R. S. (2012). Theories of Psychotherapy and Counseling: Concepts and Cases (5 ed.). California: Brooks/Cole.

Sholiha, M. (2013). Gambaran Stress dan Coping Stress pada Santri Aliyah yang Tinggal di Pondok Pesantren Asshiddiqiyah Kebon Jeruk Jakarta Barat. Gambaran Stress dan Coping Stress pada Santri Aliyah yang Tinggal di Pondok Pesantren Asshiddiqiyah Kebon Jeruk Jakarta Barat.

Steptoe, A., Wardle, J., Pollard, T. M., Canaan, L., \& Davies, G. J. (1996). Stress, social support and health-related behavior: a study of smoking, alcohol consumption and physical exercise. Journal of psychosomatic research, 41(2), 171-180.

Sulaeman, R. F., \& Joefiani, P. (2014). Studi Deskriptif Mengenai Derajat Stres dan Strategi Coping Stress Siswa Tsanawiyyah di Pesantren $X$. Universitas Padjadjaran.

Taufik, T., Ifdil, I., \& Ardi, Z. (2013). Kondisi Stres Akademik Siswa SMA Negeri di Kota Padang. Jurnal Konseling dan Pendidikan, 1(2), 143-150.

V Backović, D., Ilic Zivojinovic, J., Maksimović, J., \& Maksimović, M. (2012). Gender differences in academic stress and burnout among medical students in final years of education (Vol. 24).

Wardana, M. S., \& Dinata, M. K. (2016). Tingkat Stress Siswa Menjelang Ujian Akhir Semester di SMAN 4 Denpasar. in Jurnal Medika Udayana, 9, 1-4.

Weinstein, L., \& Laverghetta, A. (2009). College student stress and satisfaction with life. College Student Journal, 43(4). 